\title{
Pengaruh Jenis Pupuk dan Tinggi Genangan Air Terhadap Perkembangan Populasi Wereng Batang Padi Cokelat pada Tanaman Padi
}

\section{Effect of Fertilizers and Water Standing Levels to Population Growth of the Brown Planthopper on Rice Plant}

\author{
Don H. Kadja ${ }^{1}$ \\ ${ }^{1}$ Fakultas Pertanian Universitas Nusa Cendana, Nusa Tenggara Timur
}

\begin{abstract}
This research has been carried out using a combination of two factors: the type of fertilizer (siam weed compost and conventional fertilizer), and water standing levels (flooded $(5 \mathrm{~cm})$, saturated $(0 \mathrm{~cm})$, and intermittent). Results showed that in general rice treated with siam weed compost gave better results than that on conventional fertilizers. Treatment with siam weed compost-saturated gave the best results among all treatment given, although showing significant differences only on the variable plant fresh weight (66 $\pm 4,50$ $g$ ) and Nilaparvata lugens' life span. The longest life span of nymphs found on compost-saturated treatment $(21.33 \pm 3.21$ days), although not significantly different with other treatments, but significantly different with conventional fertilizer-flooded treatment (14.67 \pm 0.58 days). The shortest life span of mature stage was found on siam weed compostsaturated treatment $(9.33 \pm 0.58$ days) and the longest was on the conventional fertilizer-flooded treatment $(14,67 \pm 2.08$ days $)$.
\end{abstract}

Keywords: Nilaparvata lugens, fertilizer, water standing level

\section{INTISARI}

Penelitian ini telah dilakukan menggunakan kombinasi 2 faktor: jenis pupuk (kompos gulma siam dan pupuk konvensional), dan tingkatan pengairan (air tergenang terus-menerus $(5 \mathrm{~cm})$, air macak-macak $(0$ $\mathrm{cm}$ ), dan intermitten. Hasil penelitian menunjukkan bahwa secara umum perlakuan dengan kompos gulma siam memberikan hasil yang lebih baik dibandingkan dengan penggunaan pupuk konvensional. Perlakuan kompos dengan sistem pengairan macak-macak memberikan hasil yang terbaik pada semua perlakuan yang diberikan, walaupun menunjukkan perbedaan yang nyata hanya pada variabel berat basah tanaman (66 \pm 4 , $50 \mathrm{~g}$ ), lama hidup nimfa dan imago Nilaparvata lugens. Lama hidup nimfa yang paling panjang terdapat pada perlakuan kompos macak $(21,33 \pm 3,21$ hari), walaupun tidak berbeda secara nyata dengan perlakuan yang lain, namun berbeda secara nyata dengan perlakuan konve genang $(14,67 \pm 0,58$ hari). Pada stadia imago lama hidup yang paling singkat adalah pada perlakuan kompos macak $(9,33 \pm 0,58$ hari) dan yang paling panjang adalah pada perlakuan konve genang $(14,67 \pm 2,08$ hari).

Kata Kunci: Nilaparvata lugens, pupuk, tinggi genangan

\section{PENDAHULUAN}

Padi merupakan tanaman tropik, tetapi bisa tumbuh pada berbagai area geogrfik yang luas, dan biasanya akan memberikan hasil yang tertingi di daerah beriklim sedang (De Datta, 1981). Namun dalam budidayanya serangan hama merupakan salah satu faktor pembatas yang sangat penting. Sejak tahun 1969 saja Grist \& Lever membuat daftar lebih dari 800 spesies hama pada padi (di lapang dan dalam penyimpanan), dan Nilaparvata lugens (Stal) atau wereng batang padi coklat yang selanjutnya akan disebut WBC merupakan hama paling penting di Asia (termasuk Indonesia) sejak permulaan tahun 1970an. Bukan hanya karena kemampuannya mentransmisikan virus, tetapi juga karena kemampuan mengisapnya yang sangat merusak tanaman (Wilson \& Michael, 1981).

Kerusakan akibat WBC ini semakin maningkat karena adanya perubahan pola budidaya, misalnya penggunaan insektisida (International Rice Research Institute, 1979; Jiang et al, 2005; Untung \& Mahrub cit Untung, 2006), penggunaan varietas unggul, pola tanam, dan perubahan faktor abiotik, serta penggunaan pupuk 
yang anorganik yang tidak seimbang, misalnya pupuk $\mathrm{N}$ yang tinggi (IRRI, 1979).

Penggunaan pupuk anorganik secara terus-menerus memberikan dampak negatif terhadap tanah, yaitu menyebabkan kadar bahan organik menurun, terjadinya polusi lingkungan, menurunnya aktivitas mikroorganisme tanah, dan terjadinya pemadatan tanah. Penambahan bahan organik merupakan salah satu alternatif untuk mengurangi dampak negatif penggunaan pupuk anorganik, karena di samping mampu menyediakan nutrisi yang seimbang bagi tanaman, bahan organik dapat berfungsi memperbaiki struktur tanah, berperan sebagai sumber energi bagi mikroorganisme tanah, dan menambah kemampuan tanah untuk menahan air, serta meningkatkan kapasitas tukar kation (Hardjowigeno, 1989), serta dapat menigkatkan ketahanan tanaman terhadap serangan hama (Marschner, 1986). Salah satu bahan yang cukup menjanjikan untuk dipakai sebagai pupuk organik adalah kompos gulma siam yang selanjutnya akan disebut GS, yang dari penelitian terdahulu menunjukan kemampuannya untuk meningkatkan performa tanaman dan meningkatkan toleransi tanaman jagung terhadap serangan hama (Hastuti, 2010).

Sistem budidaya tanaman padi pada lahan sawah beririgasi yang selama ini dilakukan secara konvensional tergolong kurang efisien dalam penggunaan air karena lahan digenangi secara terus-menerus selama pertumbuhan tanaman dan cenderung mendorong peningkatkan pertumbuhan populasi WBC (IRRI, 1979). Di samping itu sistem genangan secara terus-menerus pada lahan sawah menyebabkan kehilangan $\mathrm{N}$ cukup tinggi akibat denitrifikasi (kehilangan $\mathrm{N}$ dalam bentuk gas, $\mathrm{NO}^{3-}$ akan diubah menjadi $\mathrm{N}_{2} \mathrm{O}$ dan $\mathrm{N}_{2}$,) sehingga menjadi kurang efisien. Penggenangan juga dapat memicu perubahan $\mathrm{Fe}$ menjadi Fero $\left(\mathrm{Fe}^{2+}\right)$ yang dapat menyebabkan keracunan pada tanaman padi (Gotoh \& Patrick, 1974). Sedangkan pada tanah dengan pengairan macak-macak, N dapat ditransformasi menjadi $\mathrm{NH}^{4+}$ dan $\mathrm{NO}^{3-}$ yang keduanya dapat diserap oleh tanaman padi (De Datta, 1981), serta $\mathrm{Fe}$ dirubah menjadi $\mathrm{Fe}^{3+}$ yang tidak berbahaya bagi tanaman padi, bahkan dapat meningkatkan penyerapan amonium. Dengan pangairan macak-macak ini juga menurut Sudewi (2010), peran bahan organik pada tanaman padi sawah akan terlihat lebih nyata.

\section{BAHAN DAN METODE}

Tanaman padi yang digunakan untuk uji ditanan berumur 8 hari setelah semai. Anakan padi ditanam secara tunggal dengan jarak tanam $20 \mathrm{~cm} \times 25 \mathrm{~cm}$ pada wadah yang terbuat dari plastik yang berukuran $40 \mathrm{~cm} \times 60 \mathrm{~cm}$. Sehingga dalam satu wadah ditanam 4 anakan. setiap wadah akan ditutupi dengan plastik cup transparan yang terbuat dari mylar dan kain kasa (ukurannya 130 $\mathrm{cm}$ x $40 \mathrm{~cm} \quad$ x $60 \mathrm{~cm}$ ) untuk memastikan keberadaanWBC pada pertanaman padi. Sebelum penanaman, pupuk diberikan pada tanah dalam setiap wadah: kompos gulma siam $=0,96 \mathrm{~kg}$ (setara dengan 40 ton $\mathrm{ha}^{-1}$ ), urea $=6 \mathrm{~g}$ (setara dengan $250 \mathrm{~kg} \mathrm{ha}^{-1}$ ), $\mathrm{KCL}=2,4 \mathrm{~g}$ (setara dengan $100 \mathrm{~kg} \mathrm{ha}^{-1}$ ), SP36 = 2,4 g (setara dengan $100 \mathrm{~kg}$ $\mathrm{ha}^{-1}$ ). Setiap kurungan diinfestasikan imago WBC makroptera pada saat tanaman padi berumur 4 minggu setelah tanam. Sebelum infestasi, WBC diambil dari pertanaman padi milik petani kamudian dibiakkan di laboratorium sampai 3 generasi pada suhu 29-30 ${ }^{\circ} \mathrm{C}$ (yang digunakan adalah imago dari generasi ke-3 tersebut).

Penelitian ini disusun secara faktorial yang terdiri dari 2 faktor, yaitu jenis pupuk dan tingkatan pengairan, sehingga kombinasinya menjadi: kompos dengan tinggi genangan $5 \mathrm{~cm}$ secara terus-menerus (kompos genang), kompos dengan tinggi genangan $0 \mathrm{~cm}$ (kompos macak), kompos dengan pengairan intermitten, (kompos intermitten), pupuk konvensional dengan tinggi genangan $5 \mathrm{~cm}$ secara terus-menerus (konve genang), pupuk konvensional dengan tinggi genangan $0 \mathrm{~cm}$ (konve macak), pupuk konvensional pengairan intermitten (konve intermitten).

\section{HASIL DAN PEMBAHASAN}

Variabel berat basah tanaman menunjukkan adanya perbedaan yang nyata antara perlakuan $(\mathrm{P}<0,05)$, dan perlakuan kompos macak menunjukkan hasil terbaik (gambar 1), dengan rata-rata bobot basah per rumpun adalah 23,66 $\pm 4,50 \mathrm{~g}$, dan tidak berbeda nyata dengan perlakuan kompos yang lain serta perlakuan konve intermitten. Sedangkan pada perlakuan konve genang memberikan berat basah tanaman yang paling kecil yaitu sebesar 59,65 $\pm 14,18 \mathrm{~g}$.

Seluruh perlakuan yang diberikan untuk variabel berat kering tanaman tidak memberikan perbedaan yang signifikan $(\mathrm{P}>0,05)$ (gambar 2). Tetapi berat kering tanaman yang paling tinggi ditemukan pada perlakuan kompos macak $(43,76$ 
g), dan secara berturut-turut diikuti dengan perlakuan kompos intermitten (39,76 g), kompos genang $(38,76 \mathrm{~g})$, konve macak $(38,16 \mathrm{~g})$, konve intermitten $(36,11 \mathrm{~g})$, dan konve genang $(33,98 \mathrm{~g})$. Serapan $N$ oleh tanaman juga hampir menunjukkan kecenderungan yang sama. Serapan
$\mathrm{N}$ tertinggi terdapat pada perlakuan kompos macak yaitu sebesar 28,97 g dan diikuti oleh perlakuan kompos intermitten. Sedangkan serapan $\mathrm{N}$ terendah adalah sebesar 19,52 $\mathrm{g}$ yang terdapat pada perlakuan konve genang (gambar 2).

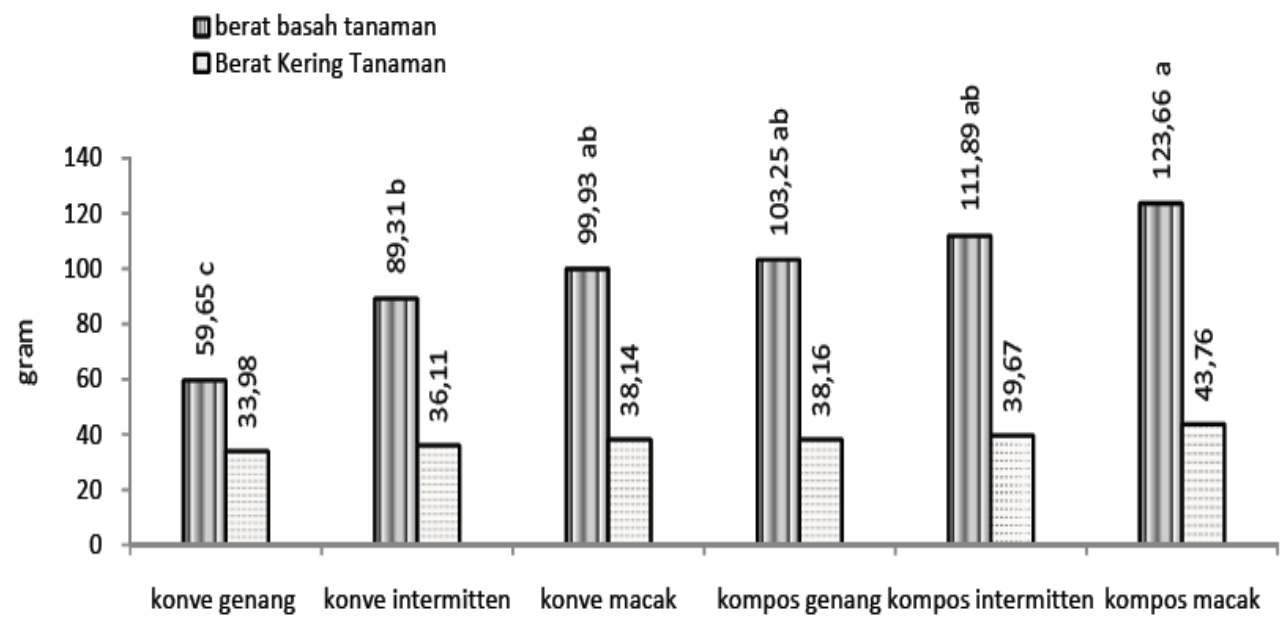

Gambar 1. Berat basah dan berat kering tanaman pada berbagai perlakuan. Nilai yang diikuti oleh huruf yang sama tidak berbeda nyata pada $\mathrm{P}>0.05$ (SAS 9.1.3)

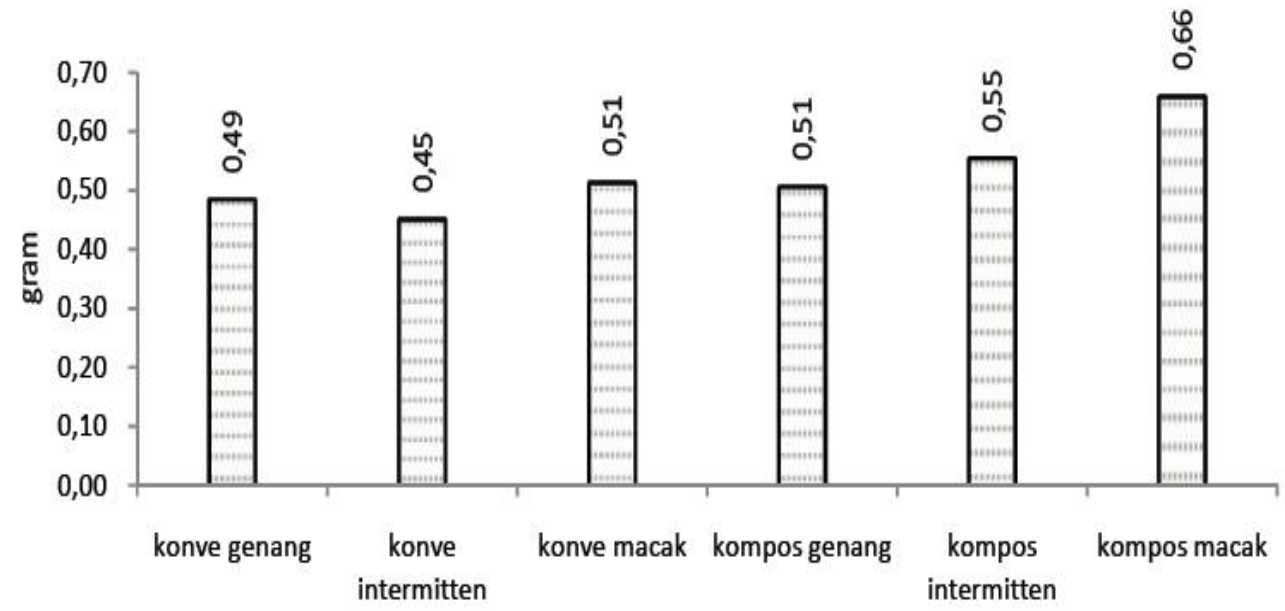

Gambar 2. Serapan N pada berbagai perlakuan

WBC merupakan serangga penghisap sap floem yang mengandung sukrosa dan senyawa $\mathrm{N}$ (Sogawa, 1982; Chino et al., 1987) dan menyebabkan penurunan laju fotosintesis dan kandungan nitrogen pada batang (Sanchez et al., 1999), serta menyebabkan terhambatnya pertumbuhan batang. Pada perlakuan konve genang terjadi penurunan berat basah yang sangat signifikan dibandingkan dengan perlakuan lain, karena serangan WBC yang sangat tinggi. Dengan kandungan $\mathrm{N}$ yang rendah menandakan bahwa banyak nutrisi dari tanaman yang telah dihisap oleh WBC. Menurut Zong-xian (2007) Pada tanaman dengan kadar nutrisi tertentu yang rendah, serangga akan meyerap lebih banyak makanan untuk memenuhi kebutuhannya akan unsur tersebut. Karena kandungan $\mathrm{N}$ yang rendah ini maka WBC lebih banyak menyerap cairan tanaman untuk memenuhi kebutuhannya akan $\mathrm{N}$ yang menurut White (1993) merupakan komponen yang paling penting sekaligus sebagai faktor pembatas pertumbuhan serangga. Oleh karena itu tanaman menjadi lebih cepat kering dibandingkan dengan tanaman pada perlakuan yang lain. Pada perlakuan kompos macak, tanaman padi menunjukkan penampilan yang 
lebih baik, hal ini karena kompos gulma siam menyediakan nutrisi yang seimbang untuk pertumbuhan tanaman padi, dan tersedianya nutrisi tersebut secara berkesinambungan membuat tanaman padi memiliki kemampuan untuk melakukan kompensasi terhadap serangan $N$. lugens, misalnya melalui perubahan mekanisme translokasi hasil asimilasi (Sanchez et al., 1999).

Lama hidup WBC mengalami perbedaan yang signifikan pada stadia nimfa dan imago $(\mathrm{P}<0,05)$.

Lama hidup nimfa yang paling lama terdapat pada perlakuan kompos macak $(21,33 \pm 3,21$ hari), walapun tidak berbeda secara nyata dengan perlakuan yang lain, tetapi tetap lebih lama dibandingkan dengan perlakuan yang lain dan secara nyata berbeda dengan perlakuan konve genang $(14,67 \pm 0,58$ hari). Pada stadia imago secara nyata lama hidup paling singkat adalah pada perlakuan kompos macak dengan lama hidup $9,33 \pm 0,58$ hari dan yang paling lama adalah pada perlakuan konve genang yaitu selama $14,67 \pm$ 2,08 hari (tabel 1).

Tabel 1. Lama Hidup Nimfa dan Imago WBC

\begin{tabular}{lcc}
\hline Perlakuan & Nimfa & Imago \\
\hline Kompos macak & $21,33 \pm 3,21 \mathrm{a}$ & $9,33 \pm 0,58 \mathrm{c}$ \\
Konve macak & $20,33 \pm 2,52 \mathrm{a}$ & $13,33 \pm 2,08 \mathrm{bc}$ \\
Konve intermitten & $19,67 \pm 2,31 \mathrm{a}$ & $13,33 \pm 0,58 \mathrm{ab}$ \\
Kompos genang & $19,33 \pm 2,08 \mathrm{a}$ & $11,67 \pm 2,08 \mathrm{ab}$ \\
Kompos intermitten & $19,00 \pm 1,73 \mathrm{a}$ & $10,00 \pm 1,00 \mathrm{c}$ \\
Konve genang & $14,67 \pm 0,58 \mathrm{~b}$ & $14,67 \pm 2,08 \mathrm{a}$ \\
\hline
\end{tabular}

Keterangan : Lama hidup nimfa dan imago WBC (mean \pm SD) yang diikuti oleh huruf yang sama tidak berbeda nyata $(\mathrm{P}>0.05)(\mathrm{SAS} 9.1 .3)$

Kandungan nitrogen yang tertinggi terdapat pada tanaman padi yang diberi perlakuan kompos macak, tetapi jumlah WBC yang selamat menjadi dewasa lebih sedikit dibandingkan dengan pada perlakuan yang lain (Tabel 1). Hal ini mengindikasikan bahwa penambahan kompos gulma siam merupakan suatu alternatif dalam meningkatkan pertumbuhan tanaman, tetapi tidak menjadi pemicu peningkatan populasi WBC.

Howard dan Sykes dalam Tompkinn \& Birds (2004) menyatakan bahwa tanaman yang diberikan pupuk dengan kombinasi unsur makro dan mikro yang seimbang memiliki kemampuan yang lebih daripada tanaman yang diberi perlakuan pupuk dengan unsur makro saja dalam menghadapi hama dan penyakit tanaman. Pada penelitian ini unsur yang ditambahkan hanyalah unsur makro N, P, K sebagai metode pemupukan umum yang dilakukan oleh petani. Sedangkan unsur-unsur mikro hanya bergantung pada ketersediaan alami pada media tanam. Terkadang unsur-unsur mikro ini terkadang dalam keadaan defisit pada tanah, tidak menunjukkan gejala yang khas pada tanaman, apalagi ditambah dengan serangan WBC, menjadi semakin sulit terlihat. Sedangkan kompos menyediakan kombinasi kedua unsur ini dengan lebih seimbang dan berkesinambungan (Winarso, 2005). Contohnya silikon (Si) merupakan unsur esensial bagi tanaman padi yang tidak tersedia melalui pupuk konvensional (Gardner et al., 2008), begitupun Kalsium (Ca) dan boron (B) yang berperan dalam perkembangan floem dan dinding sel merupakan salah satu unsur yang sangat melimpah dalam bahan organik (Winarso, 2005).

Reynolds et al dalam Da Lopez (2012) menyatakan bahwa Silikon dapat meningkatkan ketahanan tanaman inang terhadap serangga herbivora. Menurut Schoonhoven et al., (2005), ini merupakan faktor resistensi fisik yang sangat penting karena dapat menekan kemampuan penetrasi stilet serangga pencucukpengisap. Pengerasan dinding sel ini merupakan akibat dari kombinasi makromolekul seperti lignin, selulosa, suberin, calosa, dan molekul organik kecil (misalnya fenolik), serta partikel silika inorganik. Selanjutnya Reynolds et al dalam Da Lopez (2012) menambahkan bahwa deposisi silika ini memediasi pertahanan tanaman yang melibatkan berkurangnya kecernaan dan atau meningkatnya kekerasan dan abrasivitas jaringan tanaman yang secara langsung menurunkan performa serangga, dan secara tidak langsung menyebabkan penurunan jumlah serangga dan kerusakan tanaman.

Tompkin \& Bird (2004) menambahkan bahwa Pengertian N, P, dan $\mathrm{K}$ muncul hanya ketika kompos telah dimineralisasi, tapi pada saat itu nilai-nilai biologisnya telah hilang. Menurut Sabarth dalam Tompkin \& Bird (2004), ketika 
tanah hanya mempunyai mineral dan kekurangan materi-materi organik, tanaman akan terdorong untuk menyerap banyak air, sehingga mengalami kelembapan yang berlebihan. Menurutnya meskipun tanaman tersebut kelihatan bertumbuh dengan baik, namun tidak lagi dalam keseimbangan, dan karenanya sangat disukai oleh herbivora.

Kemungkinan lainnya kenapa perkembangan WBC lebih baik pada perlakuan pupuk konvensional karena adanya mekanisme bottom-up yang lebih baik pada perlakuan kompos. Menurut Russel dalam Tompkin \& Bird (2004), dalam satu gram tanah yang diberikan pupuk sampah bekas pertanian, terdapat sekitar 29 juta bakteri, dan berjuta-juta mikroorganisme lainnya. Namun ketika pupuk kimia digunakan, jumlah ini berkurang menjadi setengahnya. Interaksi antara mikroorganisme tanah dengan tanaman ini juga dapat menginduksi ketahanan tanaman terhadap herbivora pada bagian tanaman di atas permukaan tanah (Soler et al dalam Huang et al., 2012).

Hasil penelitian ini menunjukkan bahwa lama hidup nimfa WBC lebih cepat pada perlakuan konve genang. Selain berdasarkan penjelasan diatas, hal ini dimungkinkan karena keadaan kelembapan yang lebih tinggi serta kombinasi dengan pupuk $\mathrm{N}$ yang mendukung pertumbuhannya. Hal ini senada dengan banyak penelitian yang telah dilaporkan di berbagai negara, bahwa salah satu pemicu ledakan WBC adalah penggunaan pupuk $\mathrm{N}$ yang intensif (IRRI, 1979). Bahkan Schoenly et al (2010) menambahkan bahwa dengan penambahan $120 \mathrm{~kg}$ ha ${ }^{-1}$ pupuk $\mathrm{N}$ pada areal pertanian sudah akan memicu peningkatan populasi WBC. Dengan memperoleh cukup nitrogen dari tanaman imago WBC betina dapat bertahan untuk waktu yang lebih lama dan pupuk $\mathrm{N}$ meningkatkan toleransi WBC terhadap kondisi lingkungan yang merugikan (Lu et al., dalam Bottrell \& Schoenly, 2012).

\section{KESIMPULAN}

Berdasarkan hasil penelitian ini, dapat disimpulkan bahwa penggunaan kompos gulma siam yang dikombinasikan dengan sistem pengairan macak-macak dapat dijadikan sebagai suatu landasan dalam perencanaan pengelolaan Agroekosistem sawah yang lebih efisien dan relatif ramah bagi lingkungan dalam jangka waktu yang panjang, tetapi masih perlu dikaji lebih lanjut di alam terbuka kombinasi teknik budidaya ini dengan faktor-faktor alam lainnya yang hampir tidak dapat diprediksi.

\section{DAFTAR PUSTAKA}

Bottrell, D. G., K. G. Schoenly. 2012. Resurrecting the Ghost of Green Revolutions Past: The Brown Planthopper as aRecurring Threat to Highyielding Rice Production in Tropical Asia. Journal of Asia-Pacific Entomology 15 (2012) 122-140.

Chino, M., Hayashi, H., Fukumorita, T. 1987. The Chemical Composition of Rice Phloem Sap and Its Buctuation. J Plant Nutr. 10,16511661.

Da Lopes, Y. F. 2012. Kesesuaian Rumput Raja (Panicum maximum) Dan Alang-alang (Imperata cylindrica) sebagai Inang Alternatif bagi Penggerek Jagung Asia (Ostrinia furnacalis); Tesis-tidak dipublikasi. Univeritas Gadjah Mada. Yogyakarta.

De Datta, S.K. 1981. Principles and Practices of Rice Production. John Wiley \& Sons, New York

Gardner F. P., R, B, Pearce., R. L. Mitchel. 2008. Fisiologi Tanaman Budidaya; terjemahan dari Physiology of Crop Plants. UI Press. Jakarta.

Gotoh, S. H. W. H. Patrick. 1974. Transformation of Iron in Waterlogged Soil as Influenced dy Redox Potential and PH. Soil Sci. Soc. Amer. Proc., 36: 738-742.

Hardjowigeno, S. 1989. Ilmu Tanah. PT. Mediyatama Sarana Perkasa. Jakarta.

Hastuti, D. 2010. Biodiversitas Artropoda pada Pertanaman Jagung yang diberi Kompos Gulma Siam (Chromolaena odorata); Tesis. Fakultas pertanian-Universitas Gadjah Mada. Yogyakarta.

Huang, J., M. Liu., F. Chen., B. S. Griffiths., X. Chen., S. N. Johnson, F. Hu. 2012. Crop Resistance Trait Modify the Effects of an Aboveground herbivore, Brown Planthopper, on Soil Microbial Biomass and Nematode Community via Changes to Plant Performance. Soil Bio. And Biochemestry 49, 157-166.

Marschner, H. 1986. Mineral Nutrition of Higher Plants. Acadmeic Press, London.

International Rice Research Institute. 1979. Brown Planthopper: Threat to Rice Production in Asia, International Rice Research Institute. Los Banos 
Sanchez, E. R., Y. Suzuki., K. Miyamoto., T. Watanabe. 1999. The Potential for Compensation of The Efects of The Brown Planthopper Nilaparvata lugens (Stal) (Homoptera: Delphacidae) Feeding on Rice. Crop. Prot. 19:39-45.

Schoenly, K.G., Cohen, J.E., Heong, K.L.; Litsinger, J.A., Barrion, A.T., Arida, G. 2010. Fallowing Did Not Disrupt Invertebrate Fauna in Philippine lowpesticide Irrigated RiceFields. J. Appl. Ecol. 47, 593-602.

Schoonhoven, L. M., Van Loon J. J. A., Dicke M. 2005. Insect-plant Biology. Oxford University Press. UK.

Sogawa, K. 1982. The Rice Brown Planthopper: Feeding Physiology and Host Plant Interactions. Annual Review Entomology 27, 49-73

Sudewi, S. 2010, Pengaruh Tinggi Genangan Air dan Takaran Bekatul terhadap Pertumbuhan Gulma dan Hasil Padi; Tesis tidak Dipublikasikan, Fakultas Pertanian Universitas Gadjah Mada. Yogyakarta.

Tompkim, P., C. Bird. 2004. Keajaiban Tumbuhan dan Manusiapun Terkesiap oleh Rahasia Tuhan; Terjemahan dari Secret Life of The Plant. Kutub. Yogyakarta.

Untung, K. 2006. Pengantar Pengelolaan Hama Terpadu (Ed.2). Gadjah Mada University Press. Yogyakarta.

White T. C. R. The Inadequate Environment: Nitrogen and The Abundance of Animals. Berlin: Springer, 1993.

Wilson. R. W., and Michael F.C. 1981. Handbook for the Identification of Leafhoppers and Planthoppers of Rice, CAB International, London.

Winarso, S. 2005. Kesuburan Tanah; Dasar Kesehatan dan Kualitas Tanah. Gava Media. Yogyakarta.

Zhong-xian L., Y Xiao-ping., Kong-leun H., H Cui. 2007. Effect of Nitrogen fertilizer on Herbivores and Its Stimulation to Major Insect Pest in Rice. Rice Science, 2007 $.14(1): 56-66$. 